\title{
The Implementation of Using Library Card and ICT Based Library Service System in Increasing Reading Interest of Primary School Students at Tanjung Gading of Batu Bara Regency
}

\author{
Suci Amalia \\ Educational Technology Postgraduate Program \\ State University of Medan \\ Medan, Indonesia \\ suci_amalia@yahoo.com
}

\author{
Asih Menanti \\ Guidance and Counseling Course of FIP \\ State University of Medan \\ Medan, Indonesia \\ asih_menanti@yahoo.com
}

\begin{abstract}
The library as a learning resource and all at once as information sources for students related to reading activity started from the primary school level. A media is really needed to easen the students on reading study since the initial until more graduated at the school library. The library service media by means of software has been introduced to students refers to stages called AMALIA model (Attention, Memoryzing, Accelerating, Literal, Improving and Asset). The AMALIA model equipped with library card that has not been implemented previously in the school library. Objective of this study was the implementation of the library card as well as ICT-based on library service system in increasing reading interest of primary school students at Tanjung Gading of Batu Bara Regency. The study was designed by using pretest - posttest of 86 students of primary school as total samples of study subjects. The level of reading interest was measured by using the interest scale prepared by researchers that has been guaranteed of as well validity and reliability. The research result indicates that the reading interest of students to the library was higher after using library card and ICT-based library service system compared before using library card and ICT-based library service system. Based on the research result is recommended that the school management can implement the library card and ICT-based library service system in managing their school library.
\end{abstract}

Keywords-library card; library service system; AMALIA model; reading interest

\section{INTRODUCTION}

The Library is one of learning resources that can be a force to educate the nation. Library can not be separated from students' learning at school in looking for knowledge. The facilities provided by this school is very useful for all students if they can utilize the library maximally. However, not all library implement ICT in the library service system such as member registration, book searching, book lending, and others. In general library services system were conducted manually using the bookkeeping so that less efficient in time and difficulty in finding the existence status of the book, the use of library card has not been implemented previously as the identity of the user, the available books have not been arranged yet in accordance with the rules of library classification system.

The library closely related to reading activity and reading study generally starts from the primary school level so it is necessary to have a media that facilitates the children in the reading stage from the initial until more graduated, which they can find through the school library. The Stages in AMALIA model including Attention, Memoryzing, Accelerating, Literal, Improving and Assets were expected to facilitate this necessity thereby evolving into reading habit in increasing reading interest of primary school students. An interesting manner in this ICT-based library service system with AMALIA model is the involvement of students in learning on using the provided software equipped with library card. Software was made by using PHP programming language with MySQL database and of course Macromedia Flash to provide the required animation.

\section{A. Reading Interest}

An interest is a learned motive which drives the individual to act in accordance with that interest. It is defined as preoccupation with an activity when the individual is free to choose. When the child finds an activity satisfying, it continues to be an interest. Because every interest satisfies some need, the stronger the need that is being satisfied, the stronger and the more lasting the interest.

The development of interests in a child is caused by the following factors: (a) interests develop closely parallels the child's physical and mental development; (b) interest depends on learning readiness; (c) interests depends on learning opportunities; (d) interest develop possibly limitary; (e) interest influenced by cultural influences; (f) interests are markedly influenced by likes and dislikes; ( $\mathrm{g}$ ) interest is egocentric.

Because the interest role is highly important in the child's life, the interests that will help the child's personal and social adjustment need to be discovered and nurtured. There are many ways in which it is possible to find out what a child's interests are through: (a) observation activities; (b) the questions; (c) the subject matter; (d) reads; (e) draws and 
paints spontaneously; (f) wishes; (g) the others interests report [1]. One way to find a child's interest is reads, when he is free to select his books to reads or read out, select topics that interests him or as an example select a library as a learning resource and all at once as information sources.

Literally reading interest is a individual's strong desire to read or in another sense of reading interest is the cognitive and affective tendencies of the student to the reading activity, or something that is attempted to interest the reading book and develop it into reading habit. Therefore, students' reading interest needs to be developed. Developing students' reading interest should be cultivated as early as possible when someone early recognizes writing (letter).

\section{B. Library as a Learning Resource}

Learning Resources (for Educational Technology)-all of the resources (data, people, and things) which may be used by the learner in isolation or in combination, usually in an informal manner, to facilitate learning; they include Messages, People, Materials, Devices, Techniques, and Settings [2] Resource or component in Learning Resources with their definitions and examples shows in Tab. I below.

TABLE I. Learning Resources

\begin{tabular}{|l|l|l|}
\hline $\begin{array}{l}\text { Resource or } \\
\text { Component }\end{array}$ & \multicolumn{1}{|c|}{ Definition } & \multicolumn{1}{c|}{ Examples } \\
\hline Message & $\begin{array}{l}\text { Information to be transmitted } \\
\text { by the other components; takes } \\
\text { the form of ideas, facts, } \\
\text { meanings, data. }\end{array}$ & $\begin{array}{l}\text { Any subject } \\
\text { matter/content }\end{array}$ \\
\hline People & $\begin{array}{l}\text { Persons who are acting to store } \\
\text { and/or transmit Messages. }\end{array}$ & $\begin{array}{l}\text { Teacher; student; } \\
\text { speaker }\end{array}$ \\
\hline Material & $\begin{array}{l}\text { Items (traditionally called } \\
\text { media or software) which } \\
\text { usually store Messages for } \\
\text { transmission by devices. }\end{array}$ & $\begin{array}{l}\text { Filmstrip; slide; } \\
\text { audiotape; programed } \\
\text { instruction materials; } \\
\text { book; jurnal }\end{array}$ \\
\hline Device & $\begin{array}{l}\text { Items (traditionally called } \\
\text { hardware) which transmit } \\
\text { Messages stored on Materials. }\end{array}$ & $\begin{array}{l}\text { Computer output } \\
\text { devices; teaching } \\
\text { machine }\end{array}$ \\
\hline Technique & $\begin{array}{l}\text { Routine procedures or precast } \\
\text { molds for using Materials, } \\
\text { Devices, Settings, and People } \\
\text { to transmit Messages. }\end{array}$ & $\begin{array}{l}\text { Simulation, gaming, } \\
\text { discovery, team } \\
\text { teaching, discussion }\end{array}$ \\
\hline Setting & $\begin{array}{l}\text { The environment in which the } \\
\text { Messages are received }\end{array}$ & $\begin{array}{l}\text { Physical: school } \\
\text { building; library } \\
\text { Environmental: } \\
\text { lighting; heating }\end{array}$ \\
\hline
\end{tabular}

Library is one of a learning resource from the setting aspect as the environment in which the messages are received. The library collects, manages, stores, preserves, presents, and empowers information. In order for managed information to have a productive value, the information must fulfill the criteria: true, correct, fast, user friendly and ready to use.

\section{Library Card and ICT-Based Library Service System}

In order to services borrowing and returning of books running smoothly need to be prepared library card. Library card means a card issued by a library that identifying its owner as a member of a library, to borrow materials or other privileges associated with the issuing library.

ICT-based library service system implies the change from manual system to the application of computers and other modern equipment to library operations and services. Effective use of ICT in libraries increases efficiency in operations, elimininates repetitive nature of works, improves the quality and range of services, facilitates easy and wider access to all kinds of information sources, facilitates faster information communication, increases morale and motivation of library staff, facilitates cooperation and resource sharing, saves time, space and resources, improves productivity and image of the library [3].

In Library Service System, library collections classified and arranged according to the Dewey Decimal Classification (DDC) and ICT applications in libraries be necessary to include Online Public Access Catalogue (OPAC) as described below.

\section{1) Dewey Decimal Classification (DDC)}

Classification, defined as a logical system for the arragement of knowledge, has played a vital role in the course of the history of the library and information services and management. There are several universally known general classification schemes available. The Dewey Decimal Classification (DDC), a system of American origin, is the most used, studied, and discussed classification over the world.

The Dewey Decimal Classification (DDC) was published in 1876 for wider user in other libraries. The word "Dewey" in its current name is that of Melville Louis Kossuth Dewey (1851-1931), who devised the classification. The second word. "Decimal," refers to the base-ten notation that is used to denote and relate subjects. It employs Indo-Arabic numerals treated like decimal fractions. Hence the name of the classification is the Dewey Decimal Classification.

To simplify the ordinal value of the decimal fractions and for ease of arrangement, there is a convention that no number in the DDC shall have fewer than three digits. The ten main classes are now denoted as:

000 Generalities

100 Philosophy, psychology

200 Religion

300 Social Sciences

400 Language

500 Natural Sciences and Mathematics

600 Technology (Applied Sciences)

700 The Arts

800 Literature and rhetoric

900 Geography, history, and auxiliarry disciplines.

This is called the first summary of the DDC schedules. For the beginner it is the first practical step in learning the system. Decimal fractions can be expanded infinitely to accommodate new subjects, are universally understood, and reveal the intellectual hierarchy of the subjects they represent [4].

\section{2) On-line Public Access Catalogue (OPAC)}

The computerised on-line catalogue is popularly known as Online Public Access Catalogue (OPAC). OPAC is a 
computerised database of the library holdings, which can be searched in many powerful ways than manual card catalogue. OPAC can be searched locally, online, through networks, Internet and can also be made available on CD-ROM format [3].

Online Public Access Catalogues are essentially a computer based replacement of the old card catalogues and its purpose and functions almost remain the same. However, the online catalogue is a value added system, which supersedes the function of traditional catalogue. It is beyond the capabilities or card catalogue to provide keyword search, Boolean searching and to provide interactive instructions or search facilitates to users with possibility of getting outputs in the various formats and information contents they require. In a simple term, it is the machine readable catalogue in place of the card catalogue. Users have the facility to access the library house keeping operations specially circulation and it also facilitates the user to directly access the machine readable bibliographic database of the library [5].

\section{AMALIA Model}

Approaches to learning can be categorized as behavioral or cognitive [6]. Approaches to learning in AMALIA model in this study referring from any reference source related to behavioristic theory, cognitive theory and information processing theory, each of these theories contributed to building procedural in this model.

Behavioristic theory concerns behavioral changes that can be observed from the stimulus and response. If the relation between stimulus and response proceeds systematically and undergoes change, then learning is considered from incapable to be able. For example in this case someone who can not read, then through a process of learning, finally become able to read. Stimulus is any form given to students in order to help students to learn, stimulus in this study in form of alphabet letters animation from $\mathrm{A}$ to $\mathrm{Z}$ given to students, then the response in form of student reactions to the stimulus provided.

Behaviorism is the view that behavior should be explained by observable experiences, not by mental processes. For the behaviorist, behavior is everything that we do, both verbal and nonverbal, that can be directly seen or heard. Mental processes are defined by psychologists as the thoughts, feelings, and motives that each of us experiences but that cannot be observed by others [6].

Learning here is a behavioral change that occurs based on the Stimulus - Response (S-R) paradigm, which is a process of providing a specific response to stimuli coming from outside. Thorndike (1913) identifies three (3) laws of learning to explain this behavior learning process includes law of effects, law of exercise and law of readiness [7].

Cognitive theory concerns the stages of cognitive development that pass. According to cognitive theory, science is built within a person through a process of continuous interaction with the environment. Learning according to cognitive theory is perceptual.

From Piaget's theory of cognitive development (1960) concluded that children's cognitive development passed through a fixed sequence. The pattern of operations that children can perform may be thought of as a level or stage. Each level or stage is defined by how children view the world [7].

Piaget's stage of cognitive developments as follows: (1) sensorimotor, at this stage the child regulates his nature with senses (sensori) and his actions (motor); (2) preoperational, at this stage the child is still strongly influenced by the particular things gained from the experience of using the senses; (3) concrete operational, at this stage the child can make inferences from something in a real situation or by using a concrete object.; (4) formal operational, at this stage abstract reasoning abilities increase and able to consider several aspects of a situation simultaneously.

As well as information processing theory related to sensory register, rehearsal and long-term memory. Information processing theory in one source is stated as part of cognitive theory, another source represents a collaboration of behavioristic and cognitive, but other reference sources generally discuss the theory of information processing placed in a separate section.

Information processing begins when a stimulus input (e.g., visual, auditory) impinges on one or more senses (e.g., hearing, sight, touch). The appropriate sensory register receives the input and holds it briefly in sensory form. It is here that perception (pattern recognition) occurs, which is the process of assigning meaning to a stimulus input. This typically does not involve naming because naming takes time and information stays in the sensory register for only a fraction of a second. Rather, perception involves matching an input to known information [7].

Fig. 1 shows an information processing model that incorporates processing stages developed by Richard Atkinson and Richard Shiffrin (1968). According to this model, memory involves a sequence of sensory memory, short-term memory, and long-term memory stages [6].

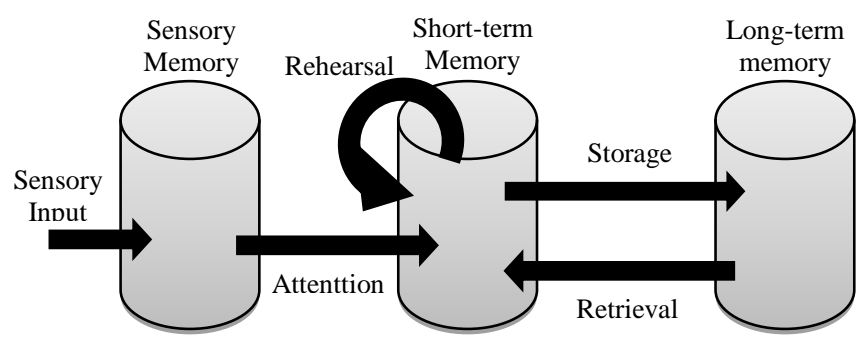

Figure 1. Information processing model of learning and memory

\section{METHOD}

\section{A. Participants and Settings}

The study sample consisted of total 86 from 87 fifth grade students of primary school collected from 3 classes in Tanjung Gading of Batu Bara Regency during the second semester of the scholastic year 2016/2017. One of the students was declared as unable to attend when pretest reading interest, so that the total number of students who participated amounted to 86 students. For library visitors open for all grade levels. 
The selection of studied schools that qualified for the implementation of library card as well as ICT-based on library service system in Tanjung Gading area was primary school IT Al-Ihya Tanjung Gading because of the availability of several computer units that can be used to realize the product of this research. Tanjung Gading is a residential area of Indonesia Asahan Aluminum (Inalum) company where the level of kindergarten until senior high school are available.

\section{B. Study Procedures}

This study is an educational research and development ( $\mathrm{R}$ $\&$ D) that will produce the product of ICT-based library service system with AMALIA model equipped with library card based on needs analysis in the field. Products in educational R \& D are not always objects shaped or hardware, such as books, modules, learning aids in the classroom or in the laboratory, but can also software, in this case the computer program for the library.

Educational R \& D is an industry-based development model in which the findings of research are used to design new product and procedures, which then are systematically fieldtested, evaluated, and refined until they meet specified criteria of effectiveness, quality, or similar standards [8].

This field test was designed by using pretest-posttest of 86 students of primary school as total samples of study subjects to compare before using library card and ICT-based library service system and after using library card and ICT-based library service system.

In the one-group pretest-posttest design, a single group is measured or observed not only after being exposed to a treatment of some sort, but also before. If a change in reading interest occurs between the pretest and the posttest, the researcher has reason to believe that it was caused by the treatment [9].

This study follows a step by step cycle, each step process used to develop the product, shows in Fig. 2 below.

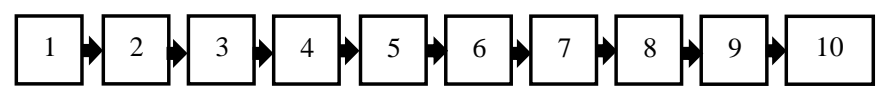

Figure 2. Research and Development Cycle

1. Research and information collecting; 2. Planning; 3. Develop preliminary form of product; 4. Preliminary field testing; 5. Operasional field testing; 6. Operasional product revision; 7. Main field testing; 8. Main product revision; 9. Final product revision; 10. Dessemination and implementation.

\section{RESULTS AND DISCUSSION}

\section{A. Product Results}

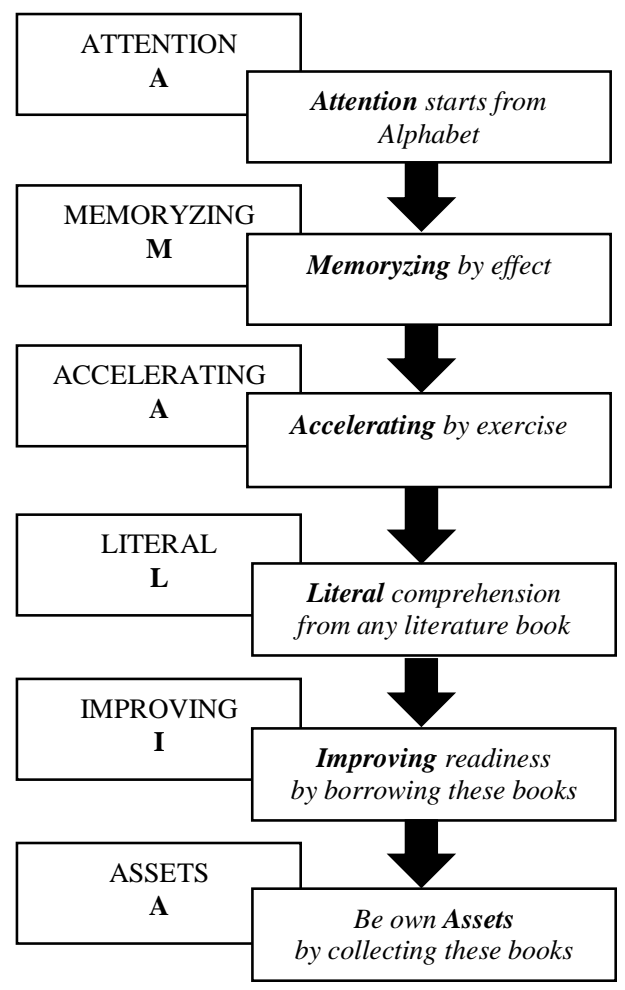

Figure 3. AMALIA model

The product results in this study according to the field needs analysis was ICT-based library service system with AMALIA model in Fig. 3 equipped with library card, the explanation for each of AMALIA stages as described below.

\section{1) A (Attention) : Attention starts from Alphabet}

This model begins by giving attention to stimuli that lead to the achievement of learning objectives, the stimulus can be a form, color, or the others that can be captured by the senses. Attention stimulation in this model in form of alphabet letters with different color display in each alphabet.

\section{2) $M$ (Memoryzing): Memoryzing by effect}

In this stage, each alphabet letter has its own animation, when the action command was activated (press key) it will show the animation of writing each letter of the alphabet itself, and can be repeated again by re-activating the script action as needed until the alphabet letter was formed in the students' cognitive structure or inherent in his memory. Memoryzing by effect means embedded in memory because of the repetition effect.

\section{3) A (Accelerating) : Accelerating by exercise}

After the students were formed their attention with the introduction of alphabet letters and then understand the animation of alphabet letters from the effects of animation, at this stage students were introduced by reading the word to a 
sentence that leads to the titles of books stored in the library books data with the spelling reading when the action script was activated, this condition was called accelerating by exercise spelling the word in sentence.

\section{4)}

4) L (Literal) : Literal comprehension from any literature

Reading literal comprehension was reading consists of letters and sentences. This stage students begin to try reading a few sentences from any literature books that available in the library. So the display presented was still an abstraction of the selected books along with other information about the book when students select one of the intended book on the display screen. books

\section{5) I (Improving) : Improving readiness by borrowing these}

This stage was the function of the library as in general, the lending phase of the selected book when clicking on the borrowing on the display screen. Then the students fill in some columns that are available besides the columns that have been automatically filled by the system. In this case improving readiness by borrowing these books (resources) means increasing willingness in form of the ability to go to the next stage by borrowing the selected books.

\section{6) A (Assets) : be own Assets by collecting these books}

Assets were defined as anything of value, owned by a person or an organization. In this service was provided facility to copy some sheets that were considered important by users (students/teachers) of the books selected for educational purposes.

\section{B. Validation Results}

In order that the research developed can illustrates the real reading interest, then an instrument was required that fulfill the validity and reliability requirements, validity was evidence that indicates the used instruments can provide accurate view of the variables to be known in accordance with objective of this study, while reliability relates to the constancy or consistency of a measuring instrument which shows in Fig. 4 and Fig. 5 below.

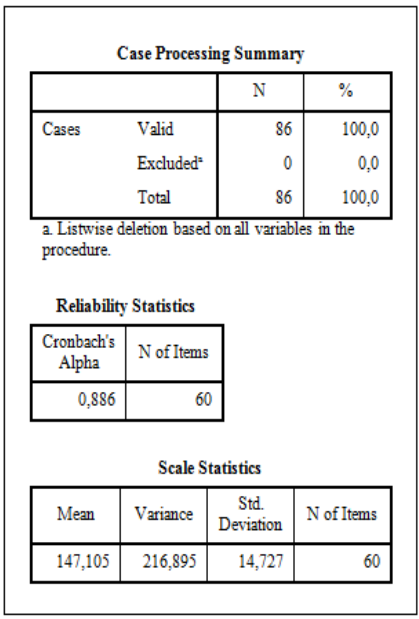

Figure 4. Reliability Pretest

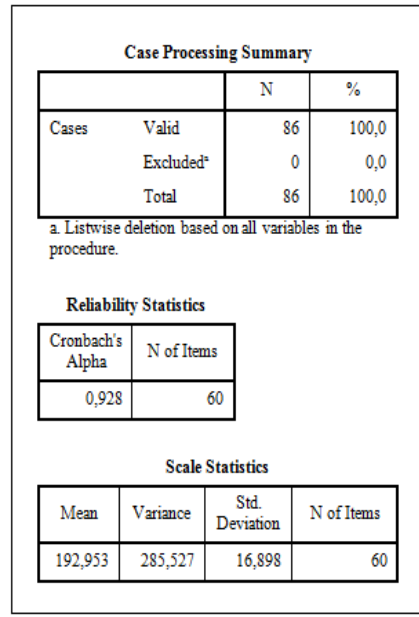

Figure 5. Reliability Posttest

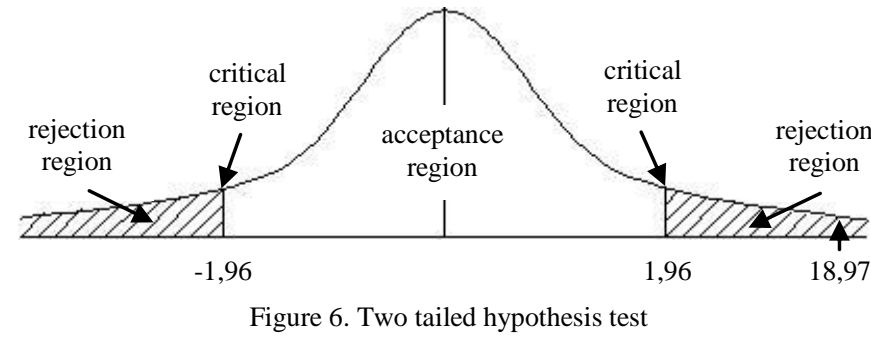

Prior to the effectiveness test, it was necessary to conducted the data requirements test, namely normality and homogeneity requirements. Normality test is used to find out whether the data is normally distributed by using Lilliefors test, while homogeneity test to find out whether the data is homogeneous by using Bartlett test.

From the calculation result of normality test for pretest obtained $\mathrm{L}$ nol $=0,0929$, with $\mathrm{n}=86$ and statistical significance alpha $=0,05$, from the table of Critical Values L for the Lilliefors Test obtained $\mathrm{Lt}=0,09554$ which is higher than $\mathrm{L}$ nol $=0,0929$ so the null hypothesis was accepted. Then for the calculation results of the posttest normality test obtained $\mathrm{L}$ nol $=0,0561$ with $\mathrm{n}=86$ and statistical significance alpha $=0,05$, from the table of Critical Values $\mathrm{L}$ for the Lilliefors Test obtained Lt $=0,09554$ which is higher than $\mathrm{L}$ nol $=0,0561$ so the null hypothesis was also accepted. The conclusion was that populations normally distributed.

Furthermore, the calculation result of homogeneity test by using Bartlett test. With Bartlett test, $\mathrm{X}$ square count $=1,62$, from Chi-square distribution table with $\mathrm{dk}=1$ on statistical significance alpha $=0,05$ obtained $\mathrm{X}$ square table $=3,84$, therefore $\mathrm{X}$ square count $=1,62<3,84$, so that obtained $\mathrm{H}$ nol accepted in statistical significance alpha $=0,05$. The conclusion was $\mathrm{X}$ square count lower than $\mathrm{X}$ square table then both groups were homogeneous.

Effectiveness test was conducted to see the significant difference between reading interest of students before using library card and ICT-based library service system and after using library card and ICT-based library service system with difference test (t test) which shows in Fig. 6 above.

From the calculation obtained $\mathrm{S}=15,85$ and $\mathrm{T}=18,97$. The formula of $(\mathrm{dk}), \mathrm{dk}=\mathrm{n} 1+\mathrm{n} 2-2$, therefore $\mathrm{dk}=170$. From table obtained $\mathrm{t}(0,05)=1,96$, the correlation criteria obtained was called significant if $\mathrm{T}$ count $>\mathrm{T}$ table on statistical significance alpha $=0,05$, because $18,97>1,96$ accordingly it was called significant or hypothesis accepted.

To calculate the system effectiveness of the applied system by using Likert Scale. Beginning with determine the ideal score first. The ideal score (criterion) is a set score with the assumption that each respondent on each question gives the answer with the highest score.

Material validation includes format aspect, content aspect and language aspect. Further media validation includes display aspect, presentment aspect and grapical aspect. While the validation of primary school teachers includes display aspect, presentment aspect, content aspect and interest aspect which shows in Tab. II below. 
TABLE II. Percentage of Average Score of Feasibility Assessmen of Each Aspect, Expert Judgements and Primary School Teachers

\begin{tabular}{|c|c|c|c|c|}
\hline \multirow[b]{2}{*}{ Aspects } & \multirow{2}{*}{$\begin{array}{c}\text { Maximum } \\
\text { Score }\end{array}$} & \multicolumn{3}{|c|}{ Validator } \\
\hline & & $\begin{array}{c}\text { Material } \\
\text { Experts }\end{array}$ & $\begin{array}{c}\text { Media } \\
\text { Experts }\end{array}$ & Teachers \\
\hline $\begin{array}{l}\text { Format } \\
\text { Aspect }\end{array}$ & 44,00 & $\begin{array}{c}39,00 \\
(88,64 \%)\end{array}$ & - & - \\
\hline \multirow{2}{*}{$\begin{array}{l}\text { Content } \\
\text { Aspect }\end{array}$} & $\begin{array}{c}\text { Material } \\
\text { Experts: } \\
32,00\end{array}$ & $\begin{array}{c}26,50 \\
(82,81 \%)\end{array}$ & - & - \\
\hline & $\begin{array}{c}\text { Primary } \\
\text { School } \\
\text { Teachers: } \\
24,00 \\
\end{array}$ & - & - & $\begin{array}{c}23,47 \\
(97,79 \%)\end{array}$ \\
\hline $\begin{array}{c}\text { Language } \\
\text { Aspect }\end{array}$ & 16,00 & $\begin{array}{c}13,50 \\
(84,38 \%)\end{array}$ & - & - \\
\hline \multirow{2}{*}{$\begin{array}{l}\text { Display } \\
\text { Aspect }\end{array}$} & $\begin{array}{c}\text { Media } \\
\text { Experts: } \\
52,00\end{array}$ & - & $\begin{array}{c}49,00 \\
(94,23 \%)\end{array}$ & - \\
\hline & $\begin{array}{c}\text { Primary } \\
\text { School } \\
\text { Teachers: } \\
20,00\end{array}$ & - & - & $\begin{array}{c}19,31 \\
(96,55 \%)\end{array}$ \\
\hline \multirow{2}{*}{$\begin{array}{c}\text { Presentment } \\
\text { Aspect }\end{array}$} & $\begin{array}{c}\text { Media } \\
\text { Experts: } \\
48,00\end{array}$ & - & $\begin{array}{c}46,50 \\
(96,88 \%)\end{array}$ & - \\
\hline & $\begin{array}{c}\text { Primary } \\
\text { School } \\
\text { Teachers: } \\
24,00\end{array}$ & - & - & $\begin{array}{c}23,63 \\
(98,46 \%)\end{array}$ \\
\hline $\begin{array}{c}\text { Graphical } \\
\text { Aspect }\end{array}$ & 20,00 & - & $\begin{array}{c}19,00 \\
(95,00 \%)\end{array}$ & - \\
\hline $\begin{array}{l}\text { Interest } \\
\text { Aspect }\end{array}$ & 8,00 & - & - & $\begin{array}{c}7,90 \\
(98,75 \%)\end{array}$ \\
\hline
\end{tabular}

\section{Product Trial Results}

The product trials were conducted after the researchers revises based on the validation result of the material experts, the media experts and the teachers, the assessment result on the product trial covers the display aspect, presentment aspect, content aspect and interest aspect. Product trials were conducted in stages starting from individual trial of 5 students, small group trial of 10 students and field trial of 86 students which shows in Tab. III below.

TABLE III. Percentage of Average Score Assessment Results Trial Phase on Each Aspect

\begin{tabular}{|c|c|c|c|c|}
\hline \multirow[b]{2}{*}{ Aspects } & \multirow[b]{2}{*}{$\begin{array}{c}\text { Maximum } \\
\text { Score }\end{array}$} & \multicolumn{3}{|c|}{ Responden } \\
\hline & & $\begin{array}{c}\text { Individual } \\
\text { Trial }\end{array}$ & $\begin{array}{c}\text { Small } \\
\text { Group } \\
\text { Trial } \\
\end{array}$ & $\begin{array}{l}\text { Field } \\
\text { Trial }\end{array}$ \\
\hline $\begin{array}{l}\text { Display } \\
\text { Aspect }\end{array}$ & 20,00 & $\begin{array}{c}15,80 \\
(79,00 \%)\end{array}$ & $\begin{array}{c}16,40 \\
(82,00 \%)\end{array}$ & $\begin{array}{c}16,47 \\
(82,35 \%)\end{array}$ \\
\hline $\begin{array}{c}\text { Presentment } \\
\text { Aspect }\end{array}$ & 24,00 & $\begin{array}{c}20,60 \\
(85,83 \%)\end{array}$ & $\begin{array}{c}20,20 \\
(84,17 \%)\end{array}$ & $\begin{array}{c}20,26 \\
(84,42 \%)\end{array}$ \\
\hline $\begin{array}{l}\text { Content } \\
\text { Aspect }\end{array}$ & 24,00 & $\begin{array}{c}19,20 \\
(80,00 \%)\end{array}$ & $\begin{array}{c}19,30 \\
(80,42 \%) \\
\end{array}$ & $\begin{array}{c}20,03 \\
(83,46 \%) \\
\end{array}$ \\
\hline $\begin{array}{l}\text { Interest } \\
\text { Aspect }\end{array}$ & 8,00 & $\begin{array}{c}7,00 \\
(87,50 \%)\end{array}$ & $\begin{array}{c}6,80 \\
(85,00 \%)\end{array}$ & $\begin{array}{c}6,99 \\
(87,37 \%)\end{array}$ \\
\hline
\end{tabular}

\section{Level of Reading Interest}

TABLE IV. Level of Reading Interest

\begin{tabular}{|c|c|c|c|c|}
\hline \multirow{2}{*}{ Class } & \multirow{2}{*}{ Amount } & \multicolumn{2}{|c|}{ Reading Interest } & \multirow{2}{*}{$\begin{array}{c}\text { Percentage } \\
\text { Increase }\end{array}$} \\
\cline { 3 - 4 } & & Pretest & Posttest & A $28,27 \%$ \\
A & 33 & 4811 & 6171 & $34,43 \%$ \\
B & 22 & 3241 & 4357 & $31,89 \%$ \\
\hline Total & 31 & 4599 & 6066 & - \\
Average & - & 12651 & 16594 & $31,17 \%$ \\
\hline
\end{tabular}

The level of reading interest was measured by using the interest scale that has been guaranteed of as well validity and reliability. Tab. IV shows the reading interest of students to the library was higher after using library card and ICT-based library service system compared before using library card and ICT-based library service system. Based on the research result is recommended that the school management can implement the library card and ICT-based library service system in managing their school library.

\section{ACKNOWLEDGMENT}

I would like to express my thanks to my supervisors for providing me their invaluable guidance, suggestions and comments throughout this study, to technical implementation unit staffs of Digital Library State University of Medan as the expert judgement on material, to lecturers of Educational Technology Postgraduate Program State University of Medan as the expert judgement on media, furthermore the principal and teachers of primary school in primary school IT Al-Ihya Tanjung Gading as the validator teacher for this study, especially to my whole family for their unceasing encouragement and support.

\section{REFERENCES}

[1] E.B. Hurlock, Child Development. New York, NY: McGraw-Hill, 1978, pp. 440-479.

[2] AECT, The Definition of Educational Technology. Washington, D.C. : Association for Educational Communication and Technology, 1977, pp. 89.

[3] P.V. Ramana, Information Technology Applications in Libraries. New Delhi: Ess Ess Publications, 2004, pp. 24-66.

[4] L.M. Chan, J.P. Comaromi, J.S. Mitchell, and M.P. Satija, Dewey Decimal Classification. Albany, NY: OCLC Online Computer Library Center, 1996, pp. 1-10.

[5] A.K. Dhiman, Basics of Information Technology for Librarians and Information Scientists, vol. II : IT's Applications in LIS. New Delhi: Ess Ess Publications, 2003, pp. 73-105.

[6] J.W. Santrock, Educational Psychology, 5th ed. New York, NY: McGrawHill, 2011, pp. 216-293.

[7] D.H. Schunk, Learning Theories: An Educational Perspective, 6th ed. Boston, MA: Pearson Education, 2012, pp. 98-388.

[8] M.D. Gall, J.P. Gall, and W.R. Borg, Educational Research: An Introduction, 7th Edition. Boston, MA: Allyn and Bacon, 2003, pp. 569576.

[9] J.R. Fraenkel and N.E. Wallen, How to Design and Evaluate Research in Education, 7th ed. New York: MgGraw-Hill Higher Education, 2008, pp. 265-266. 